\title{
ARAŞTIRMA / RESEARCH \\ Efficacy of preoperative neutrophil-to-lymphocyte ratio in determining lymph node metastases in testicular cancer
}

Testis kanserinde lenf nodu metastazını göstermede preoperatif nötrofil lenfosit oranının etkinliği

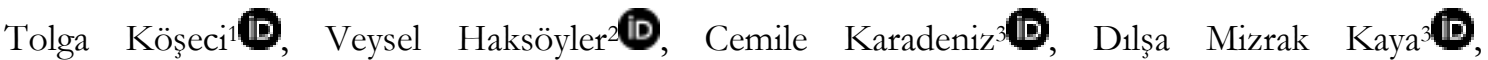

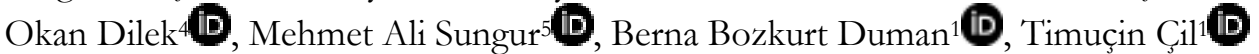

${ }^{1}$ University of Health Science, Adana City Teaching and Research Hospital, Department of Medical Oncology, ${ }^{4}$ Department of Radiology, Adana,Turkey

${ }^{2}$ Medline Hospital, Department of Medical Oncology, Adana,Turkey

${ }^{3}$ İskenderun Statement of Hospital, Department of Medical Oncology, Hatay,Turkey

5Düzce University Faculty of Medicine, Department of Biostatistics and Medical Informatics, Düzce, Turkey

\section{Abstract}

Purpose: Testicular cancer is the most common solid tumor in young men between the ages of 20-35 and has excellent clinical outcomes with appropriate treatment. Neutrophil-to-lymphocyte-ratio (NLR) is related with prognosis and relapse in different solid tumors. We aimed to investigate the relation of presence and size of regional lymph node metastasis with NLR in testicular cancer.

Materials and Methods: A total of 72 testicular cancer patients were included in the study. All medical records were retrospectively collected. NLR was calculated as the count of neutrophil divided by the count of lymphocyte. Chest and abdomen computed tomograpy (CT) scans of all patients were evaluated for metastases.

Results: The mean age was $32.18 \pm 8.89$ years. The pathologic classification was seminoma in $43 \%$ and nonseminoma in $57 \%$ of patients. Of 72 patients, 32 $(44.4 \%)$ had lymph node positivity and $40(55.6 \%)$ hadnot. The mean NLR value was $2.63 \pm 1.79$ for all cohort. The mean NLR was significantly lower in patients with lymph node negative disease (for lymph node positive and negative disease $3.19 \pm 2.32$ and $2.25 \pm 1.06$, respectively.). In the ROC analysis, 2.5 was determined as the cut-off value for NLR to assess lymph node status. Conclusion NLR is a cheap and readily available index that can be used to determine lymph node metastases in testicular GCTs.

Keywords:. Germ cell tumor, testicular cancer, neutrophil lymphocyte ratio, lymph node metastases

\section{Öz}

Amaç: Testis kanseri 20-35 yaş arası genç erkeklerde en s1k görülen solid tümördür ve uygun tedavi ile çok iyi klinik sonuçlara sahiptir. Nötrofil-lenfosit oranının (NLR), farklı solid tümörlerde prognoz ve nüks ile ilişkili olduğu gösterilmiştir. Testis kanserinde lenf nodu metastazını varlığını göstermede NLR ile ilişsisini araştırmayı amaçladık.

Gereç ve Yöntem: Çalışmaya toplam 72 testis kanseri hastası alındı. Tüm veriler geriye dönük olarak toplandı. NLR, nötrofil sayısının lenfosit sayısına bölünmesiyle hesapland. Tüm hastaların toraks ve batın bilgisayarlı tomografi (BT) taramaları metastaz açısından değerlendirildi.

Bulgular: Ortalama yaş 32.18 \pm 8.89 idi. Patolojik sınıflama hastaların \%43'ünde seminom ve \%57'sinde nonseminom şeklindeydi. 72 hastanın 32 'sinde $(\% 44,4)$ lenf nodu pozitif, 40 'inda $(\% 55,6)$ lenf nodu negatifti. Hastaların ortalama NLO değeri $2,63 \pm 1,79$ idi. Ortalama NLO, lenf nodu negatif hastalığ olan hastalarda anlamlı olarak daha düşüktü (lenf nodu pozitif hastalık için $3.19 \pm 2.32$ ve lenf nodu negatif hastalık için $2.25 \pm 1.06$ ). ROC analizinde, lenf nodu durumunu değerlendirmek için NLR için cut-off değeri olarak 2.5 belirlendi.

Sonuç: Çalışma verilerimiz, NLR'nin testiküler GHT'lerde lenf nodu metastazlarını belirlemede kullanılabilecek düşük maliyetli ve hazır bir indeks olduğunu göstermektedir.

Anahtar kelimeler: Germ hücreli tümör, testiküler kanser, nötrofil lenfosit oran1, lenf nodu metastazı 


\section{INTRODUCTION}

Testicular cancer (TC) is an rare tumor and makes less than $1 \%$ of all male cancers ${ }^{1}$. However, it is the most common solid tumor in young men between the ages of 20-35 and has excellent clinical outcomes. Most of the patients have early-stage cancer at diagnosis and only $10 \%$ has metastatic disease. Testicular germ cell tumors (GCTs) comprise almost $95 \%$ of all testicular cancers ${ }^{2}$. GCTs have two histologic subgroups as seminoma and nonseminoma. Risk factors for testicular cancer development are presence of contralateral TC history, history of cryptorchidism, familial history of $\mathrm{TC}^{2}$.

Inflammation plays an important role in the development, progression and prognosis of several different solid tumors ${ }^{3}$. It is reported that neutrophil and platelet count, level of C-reactive protein and neutrophil-to-lymphocyte-ratio (NLR) has an impact on in the prognosis of various types of cancers ${ }^{4}$. Cytokines elevated in inflammatory response can facilitate angiogenesis, tumor development, growth and metastases ${ }^{5}$. NLR is a feasible prognostic index as a cheap and easy-to-use method in routine clinical practice. NLR can be calculated by dividing the number of neutrophils by the number of lymphocytes. It has been shown that NLR is related with prognosis and relapse in different solid tumors ${ }^{6}$.

In the present study, we aimed to investigate the relation of presence and size of regional lymph node metastasis with NLR in testicular cancer. To the best of our knowledge, this is the first study that has been conducted to assess the relation of NLR and regional lymph node positivity in testicular cancer patients who do not have visceral organ metastases.

\section{MATERIALS AND METHODS}

\section{Sample}

A total of 72 patients that underwent orchiectomy and pathologically diagnosed as GCT of testis between January 2015 and April 2020 were included in the study. The study was carried out with Adana City Training and Research Hospital's ethics committee approval (08/04/2020, decision no:794). This hospital is a well-established training hospital affiliated to the University of Health Sciences, which provides specialty and subspecialty training. Patient information is stored safely in the patient information system and shared with the Ministry of Health. No patients received chemotherapy prior to these blood results. Demographic and clinicopathologic variables of patients were collected retrospectively from medical records. Likewise, chest-abdomen and pelvis computed tomograpy (CT) scans of all patients that had performed just after diagnosis were evaluated by radiologist who has 8 years experience retrospectively for metastases. The tumor $(\mathrm{T})$, node $(\mathrm{N})$, and metastasis (M) staging system was used to stage patients. The presence of lymph nodes with a short axis $<2 \mathrm{~cm}$ was accepted as N1; if $>2$ and $\leq 5 \mathrm{~cm}, \mathrm{~N} 2$; and $>5 \mathrm{~cm}$ as $\mathrm{N} 3$.

Patients under 18 years old; patients with ongoing or chronic infection, other malignancies, end stage liver or kidney disease, hematologic diseases; patients under anticoagulant or immunsupresive therapy, and have visseral metastases were excluded from the study. Accordingly, eight patients with visceral metastasis and two patients with acute infection were not included in this study.

\section{Laboratory analysis}

Venous blood samples were taken in tubes containing ethylenediamine tetra-acetic acid. Neuthrophil count, lymphocyte count, mean eritrocyte volume and eritrocyte distrubition width had been measured by Beckman Coulter DXH 780 in the last 7 days before orchiectomy. Also all patients had post-orchiectomy alpha-fetoprotein (AFP), beta-human chorionic gonadotropin (beta-hCG) and lactate dehydrogenase $(\mathrm{LDH})$ serum levels. AFP and beta-hCG were measured by Beckman Coulter DxI 800. NLR was calculated as the count of neutrophil divided by the count of lymphocyte.

\section{Statistical analysis}

Continuous variables were summarized in mean and standard deviation while categorical data were summarized as frequency and percentage. Independent sample test was used to compare two groups while One-Way ANOVA was used for three or more groups. Chi-square or Fisher-FreemanHalton test, according to the expected counts, was used to evaluate bivariate associations between categorical variables. A receiver operating characteristic (ROC) analysis was constructed to determine the best cut-off value to predict the lymph node positivity. Statistical analyses were performed by SPSS v.20 software program. $\mathrm{p}<0.05$ values were considered statistically significant. 


\section{RESULTS}

Demographic, clinical and pathological characteristics of all 72 patients are summarized in Table 1 . The mean age was $32.18 \pm 8.89$ years. The pathologic classification was seminoma in $43 \%$ and nonseminoma in $57 \%$ of patients. Of 72 patients 32 (44.4\%) had positive lymph nodes and 40 (55.6\%) had not. Serum tumor marker classification was $\mathrm{S} 0$ in $43.1 \%$, S1 in $55.6 \%$, and S2 in $1.3 \%$ of patients. None of the patients had S3 level tumor markers. The mean NLR value was $2.63 \pm 1.79$ for all cohort.

Table 1. Demographic, clinical and pathological characteristics of patients

\begin{tabular}{|c|c|c|}
\hline \multicolumn{2}{|l|}{ Age (years) } & $32.18 \pm 8.89$ \\
\hline \multicolumn{2}{|l|}{ Tumor size $(\mathrm{mm})$} & $47.58 \pm 17.56$ \\
\hline \multirow[t]{2}{*}{ Primary tumor location } & Right & $37(51.4 \%)$ \\
\hline & Left & $35(48.6 \%)$ \\
\hline \multirow[t]{4}{*}{ Serum tumor marker staging } & S0 & $31(43 \%)$ \\
\hline & S1 & $40(55.5 \%)$ \\
\hline & $\mathrm{S} 2$ & $1(1.3 \%)$ \\
\hline & S3 & 0 \\
\hline \multirow[t]{4}{*}{$\mathrm{N}$ staging } & N0 & $40(55.5 \%)$ \\
\hline & N1 & $4(5.6 \%)$ \\
\hline & N2 & $18(25 \%)$ \\
\hline & N3 & $10(13.9 \%)$ \\
\hline \multirow[t]{9}{*}{ TNM staging } & IA & $8(11.4 \%)$ \\
\hline & $\mathrm{IB}$ & $22(30.5 \%)$ \\
\hline & IS & $10(13.8 \%)$ \\
\hline & IIA & $8(11.1 \%)$ \\
\hline & IIB & $12(16.6 \%)$ \\
\hline & IIC & $7(9.7 \%)$ \\
\hline & IIIA & $2(2.7 \%)$ \\
\hline & IIIB & $3(4.2 \%)$ \\
\hline & IIIC & 0 \\
\hline \multicolumn{3}{|l|}{ Tumor histology } \\
\hline \multicolumn{2}{|l|}{ Seminoma } & $31(43 \%)$ \\
\hline \multirow[t]{4}{*}{ Nonseminoma } & Embryonal carcinoma & $19(26.4 \%)$ \\
\hline & Yolk sac tumor & $6(8.4 \%)$ \\
\hline & Teratoma & $4(5.6 \%)$ \\
\hline & Mixed germ cell tumor & $12(16,6 \%)$ \\
\hline \multicolumn{2}{|l|}{ Neutrophil count } & $5053.88 \pm 2527.13$ \\
\hline \multicolumn{2}{|l|}{ Lymphocyte count } & $2169.86 \pm 829.47$ \\
\hline \multicolumn{2}{|l|}{ Neutrophil-to-lymphocyte ratio } & $2.63 \pm 1.79$ \\
\hline \multicolumn{2}{|l|}{ Mean platelet volume } & $9.50 \pm 1.44$ \\
\hline \multicolumn{2}{|l|}{ Erythrocyte distribution width } & $13.9 \pm 1.73$ \\
\hline
\end{tabular}

N: node, TNM: tumor, node, metastasis

When the demographic, clinical and pathological characteristics of seminoma and nonseminoma patients were compared, the only statistically different variable was the age at diagnosis. The mean age of nonseminoma patients was smaller than the mean age of seminoma patients $(29.61 \pm 7.87$ years $v$ s. $35.58 \pm 9.30$ years, $\mathrm{p}=0.004)$.

The mean age was $31.53 \pm 8.85$ and $32.70 \pm 9.12$ for the patients with lymph node positive and negative disease, respectively (Table 2 ). The size of the tumor was similar in both groups $(48.52 \pm 20.98 \mathrm{~mm}$ for lymph node positive disease vs. $47.05 \pm 15.13 \mathrm{~mm}$ for lymph node negative disease, $\mathrm{p}=0.73$ ). The mean NLR was significantly lower in patients with lymph node negative disease (for lymph node positive disease $3.19 \pm 2.32$ and for lymph node negative disease $2.25 \pm 1.06, p=0.04)$. Due to the significant difference of NLR in lymph node positive and negative disease, ROC curve analysis was done (Figure 1). In ROC analysis, 2.5 was determined as the cut-off value for NLR to assess lymph node 
status. There was no significant difference in the neutrophil count, lymphocyte count, primary tumor location and pathologic characteristics of patients with lymph node positive and negative disease.

Table 2. Patient characteristics based on lymph node metastases

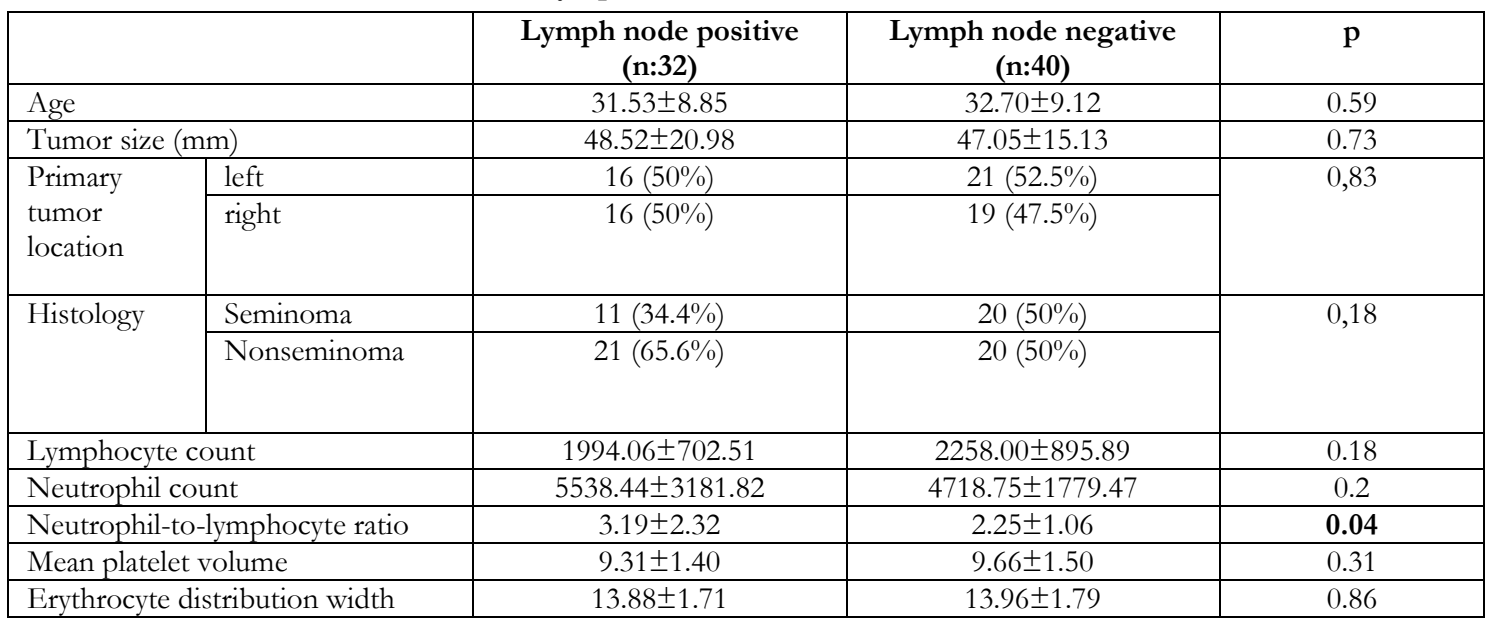

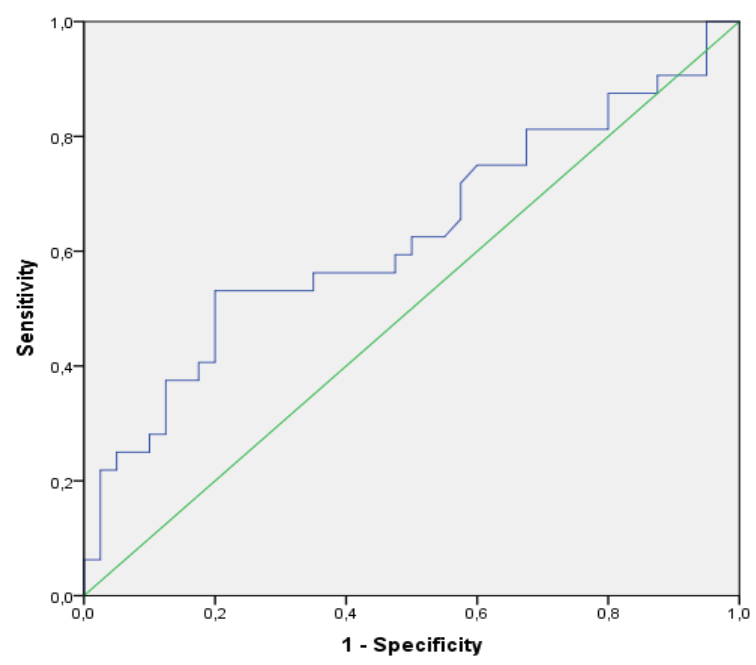

Figure 1. Receiver operating characteristic curve for neutrophil to lymphocyte ratio

When clinical and pathological characteristics of lymph node positive patients were compared between N1, N2, and N3 disease, the only significantly different variable was tumor size (Table $3)$. There was no significant difference between the NLR of N1, N2, and N3 disease. Of the total 72 patients, 47 had a NLR value less than 2.5 and 25 had a value more than 2.5 (Table 4). For the patients with a NLR $\geq 2.5$, regional lymph node metastasis was significantly higher than patients with NLR $<2.5$ $(\mathrm{p}=0.003)$. Of 47 patients with a NLR $<2.5,32$ $(68.1 \%)$ had lymph node negative disease. However, for the 25 patients with a NLR $\geq 2.5$, only $8(32 \%)$ had lymph node negative disease.

Moreover, N3 disease was also significantly higher in patients with a NLR $\geq 2.5$ compared with the patients with a NLR $<2.5(p=0.005)$. 
Table 3. Characteristics of lymph node positive patients

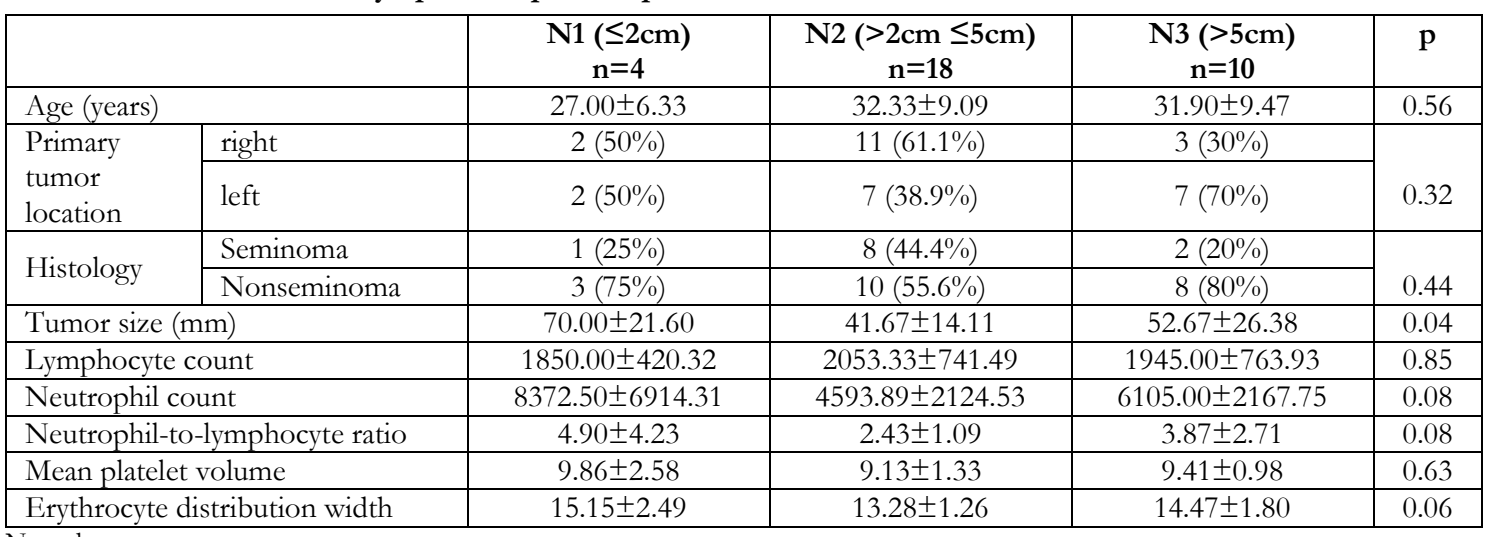

$\mathrm{N}$ : node

Table 4. Comparison of patients' characteristics based on NLR value

\begin{tabular}{|c|c|c|c|c|}
\hline \multicolumn{2}{|c|}{ 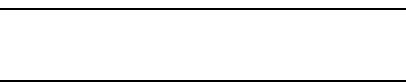 } & $\begin{array}{c}\mathrm{NLR}<2.5 \\
(\mathrm{n}=47)\end{array}$ & $\begin{array}{c}\mathrm{NLR} \geq 2.5 \\
(\mathrm{n}=25)\end{array}$ & $\mathrm{p}$ \\
\hline \multicolumn{2}{|c|}{ Age (years) } & $33.26 \pm 9.40$ & $30.16 \pm 7.85$ & 0.17 \\
\hline \multicolumn{2}{|c|}{ Tumor size $(\mathrm{mm})$} & $48.49 \pm 18.10$ & $46.13 \pm 17.45$ & 0.6 \\
\hline \multirow{2}{*}{$\begin{array}{l}\text { Primary } \\
\text { tumor } \\
\text { location }\end{array}$} & right & $26(55.3 \%)$ & $11(44 \%)$ & \multirow[b]{2}{*}{0.36} \\
\hline & left & $21(44.7 \%)$ & $14(56 \%)$ & \\
\hline \multirow[t]{2}{*}{ Histology } & Seminoma & $24(51.1 \%)$ & $7(28 \%)$ & \multirow[b]{2}{*}{0.06} \\
\hline & Nonseminoma & $23(48.9 \%)$ & $18(72 \%)$ & \\
\hline \multicolumn{2}{|c|}{ Lymph node positive } & $15(31.9 \%)$ & $17(68 \%)$ & 0.003 \\
\hline \multicolumn{2}{|c|}{ Lymph node negative } & $32(68.1 \%)$ & $8(32 \%)$ & 0.003 \\
\hline \multicolumn{2}{|c|}{ N1 } & $1(2.1 \%)$ & $3(12 \%)$ & $>0.05$ \\
\hline \multicolumn{2}{|l|}{$\mathrm{N} 2$} & $11(23.4 \%)$ & $7(28 \%)$ & $>0.05$ \\
\hline \multicolumn{2}{|l|}{ N3 } & $3(6.4 \%)$ & $7(28 \%)$ & 0.005 \\
\hline
\end{tabular}

N: node, NLR: Neutrophil-to-lymphocyte-ratio

\section{DISCUSSION}

In the present study, we showed that NLR value is a feasible index to determine lymph node positivity in testicular cancer patients without visceral organ metastasis. For the patients with a NLR $\geq 2.5$ clinicians should be more suspicious about lymph node metastasis and treatment decision.

Testicular GCTs can be localized (stage I disease) or non-localized (stage II and III disease) at diagnosis. In our study, we excluded patients with visceral organ metastases. Due to the excellent outcomes with correct treatment strategy, it is important to discriminate localized and non-localized disease ${ }^{7}$.

Systemic inflammation can change the levels of different hematologic and biochemical parameters. The most common ones are neutrophil, lymphocyte, and leukocyte count. Neutrophilia as an inflammatory response can cause tumor progression and angiogenesis by the increased synthesis of vascular endothelial growth factor and hepatocyte growth factor ${ }^{8}$. Cytokines like IL-1 and IL-6 are responsible for the neutrophilia in cancer patients 9 . It is reported that activated neutrophils can suppress lymphocytes and their anti-tumor activity ${ }^{10}$. In this study, we showed increased neutrophil and decreased lymphocyte count in patients with lymph node metastases, but this finding was not statistically significant. This can be related to the size of the cohort.

It is known that NLR is a reliable index to determine systemic inflammation. Moreover, it is feasible due to being low-cost and readily available in daily clinical practice. However, there are only a few studies about NLR in testicular cancer. It is reported that NLR is related with prognosis in different solid tumors ${ }^{11}$. Wei at al. showed that increased NLR is a poor prognostic factor in renal and bladder cancer ${ }^{12}$. There are inconsistent results about the prognostic value of 
NLR in testicular cancer. In the study of Jankovich et al., significantly higher prevalence of localized disease in testicular cancer patients with a NLR $<4$ is shown ${ }^{13}$. However, it is not mentioned how the cutoff value was determined and also they did not make any discrimination between lymph node and visceral organ metastasis. In a different study, Bolat et al. reported two different cut-off NLR values in testicular cancer for progression-free survival and cancer specific survival as 3.55 and 3, respectively. In their relatively small cohort, 53 patients, they could not demonstrate any relationship between NLR value and survival ${ }^{14}$. In a recent study, Ilktac et al. showed a significantly decreased NLR value after orchiectomy for localized testicular cancer patients. Moreover, consistent with our results, they showed significant difference between mean NLR values of localized and non-localized disease. Unlike this study, in ours, we did not include the patients with visceral metastasis. In another study, $\mathrm{Yu}$ et al. also reported an NLR cut-off value of 3.0. For the patients with a NLR $\geq 3.0$, lymph node metastasis rate was significantly higher in concordance with our results ${ }^{15}$. However, similarly in other reports they also include the testicular cancer patients with visceral metastasis. In a study which was performed by Arıman et al, NLR was high in patients with testicular cancer those than healthy control group and difference was statistically significant ${ }^{16}$.

Unlike previous studies, we also evaluated the relation between NLR value and metastatic lymph node size. We showed that patients with $\mathrm{NLR} \geq 2.5$ have significantly more N3 disease.

To the best of our knowledge, this report is the first study to assess the value of NLR as an index to determine lymph node status in a homogenous group of testicular cancer patients who do not have visceral metastases. Our study has some limitations since it is a single center study and retrospectively designed. Further research is warranted to evaluate NLR as an index in determining prognosis, at staging and for follow-up of GCT of testis. Moreover, NLR can be a good index in helping to discriminate between viable residual tumor and necrotic or fibrotic tissue after treatment.

In conclusion, NLR is a low-cost and readily available index that can be used to determine lymph node metastases in testicular GCTs. Especially for the patients with suspicious lymph node metastases in imaging studies, NLR can be a helpful index in treatment decisions.

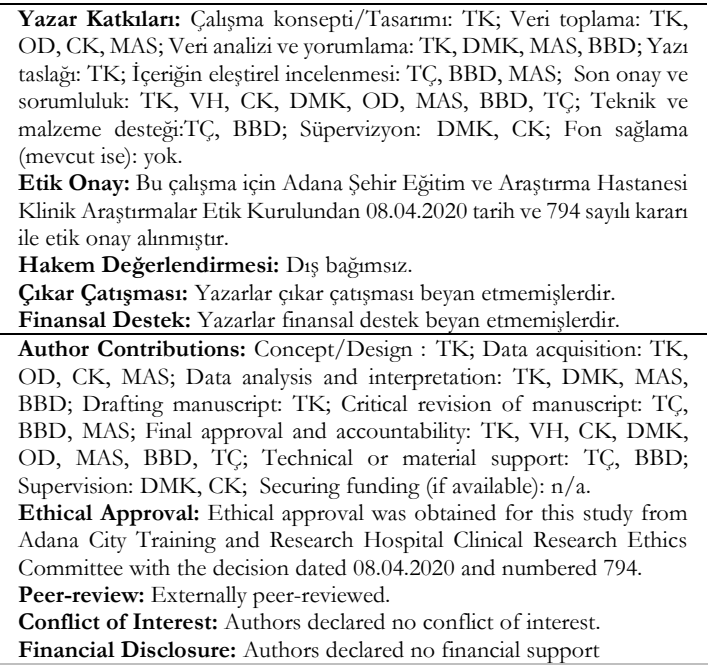

\section{REFERENCES}

1. Znaor A, Lortet-Tieulent J, Jemal A, Bray F. International variations and trends in testicular cancer incidence and mortality. Eur Urol. 2014;65:1095-106.

2. Albers P, Albrecht W, Algaba F, Bokemeyer C, CohnCedemark $G$, Fizazi $\mathrm{K}$ et al. EAU guidelines on testicular cancer: 2011 update. European Association of Urology. Actas Urol Españolas. 2012;36:127-45.

3. Mantovani A, Allavena P, Sica A, Balkwill F. Cancerrelated inflammation. Nature. 2008;454:436-44.

4. Roxburgh CSD, Crozier JEM, Maxwell F, Foulis AK, Brown J, Mckee RF et al. Comparison of tumourbased (Petersen Index) and inflammation-based (Glasgow Prognostic Score) scoring systems in patients undergoing curative resection for colon cancer. Br J Cancer. 2009;100:701-06.

5. Lu H, Ouyang W, Huang C. Inflammation, a key event in cancer development. Mol Cancer Res. 2006;4:221-33.

6. Viers BR, Boorjian SA, Frank I, Robert F, Prabin T, Jeffrey $\mathrm{K}$ et al. Pretreatment neutrophil-tolymphocyte ratio is associated with advanced pathologic tumor stage and increased cancer-specific mortality among patients with urothelial carcinoma of the bladder undergoing radical cystectomy. Eur Urol. 2014;66:1157-64.

7. Chung P, Warde P. Testicular cancer: germ cell tumours. BMJ Clin Evid. 2016;201:1807.

8. Yoka HK, Wendy AD, Geke H, Coby M, Nanno M. Platelets and granulocytes, in particular the neutrophils, form important compartments for circulating vascular endothelial growth factor. Angiogenesis. 2003;6:283-87.

9. Hanbyoul C, Hye Won H, Sang Wun K, Sung Hoon K, Jae Hoon K, Young Tae K et al. Pre-treatment neutrophil to lymphocyte ratio is elevated in epithelial 
ovarian cancer and predicts survival after treatment. Cancer Immunol Immunother. 2009;58:15-23.

10. el-Hag A, Clark RA. Immunosuppression by activated human neutrophils. Dependence on the myeloperoxidase system. J Immunol. 1987;139:240613.

11. Arnoud T, Mairéad M, Boštjan Š, Francisco Vera B, Priya A, Alberto O et al. Prognostic role of neutrophilto-lymphocyte ratio in solid tumors: A systematic review and meta-analysis. J Natl Cancer Inst. 2014;106:1-11.

12. Wei Y, Jiang YZ, Qian WH. Prognostic role of NLR in urinary cancers: A meta-analysis. PLoS One. 2014;18;9:e92079.

13. Jankovich M, Jankovichova T, Ondrus D BJ.
Neutrophil-to-lymphocyte ratio as a predictor of preoperative tumor staging in testicular germ cell tumors. Bratisl Med J. 2017;118:510-12.

14. Bolat D, Aydoğdu Ö, Polat S, Serkan Y, İbrahim B, Tark $Y$ et al. Predictive value of preoperative neutrophil-to-lymphocyte ratio on the prognosis of germ cell testicular tumors. Turk Urol Derg. 2017;43:55-61.

15. Tan YG, Sia J, Huang HH, Lau WKO. Neutrophil-tolymphocyte ratio independently predicts advanced pathological staging and poorer survival outcomes in testicular cancer. Investig Clin Urol. 2019;60:176-83.

16. Arıman A, Merder E. The prognostic importance of neutrophil-to-lymphocyte ratio in testicular cancer. Urologia. 2021; doi: 10.1177/0391560321993584. 